\title{
Repeated ruminal dosing of Ruminococcus spp. does not result in persistence, but changes in other microbial populations occur that can be measured with quantitative 16S-rRNA-based probes
}

\author{
Denis O. Krause, ${ }^{1}$ Rowan J. Bunch, ${ }^{1}$ Lawrence L. Conlan, ${ }^{1}$ \\ Peter M. Kennedy, ${ }^{1}$ Wendy J. Smith, ${ }^{1}$ Roderick I. Mackie ${ }^{2}$ \\ and Christopher S. McSweeney ${ }^{1}$
}

1 CSIRO Livestock Industries, Long Pocket Laboratories, Indooroopilly, Brisbane, Qld 4068, Australia

2 Department of Animal Sciences, University of Illinios, Urbana, IL, USA
Author for correspondence: Denis O. Krause. Tel: +6173214 2723. Fax: +61732142881. e-mail: denis.krause@1i.csiro.au.

\begin{abstract}
Digestibility of fibre in ruminants may be improved by the introduction of highly fibrolytic strains of ruminal bacteria. This approach may be feasible if, for example, strains of Ruminococcus that are significantly more fibrolytic than the normal population of Ruminococcus are used for inoculation purposes. Introduced strains of bacteria, irrespective of ecosystem, often decline after inoculation, and in this study, highly fibrolytic strains of Ruminococcus were continuously dosed to ensure that measurements of fibre digestion were made in the presence of significant numbers of the introduced bacteria. During dosing the total culturable count increased significantly $(P<0.05)$, but declined post-dosing. The level of dosed Ruminococcus, and total Ruminococcus, Fibrobacter succinogenes and eukaryotes measured by 165 rRNA probes increased significantly $(P<0.05)$ during the dosing period, but also declined post-dosing. When in vitro nylon bag digestibility, feed intake or whole-tract digestibility was measured, no improvement could be measured.
\end{abstract}

Keywords: Fibrobacter succinogenes, eukaryotes, ecology, fibre, cellulose digestibility

\section{INTRODUCTION}

Cellulose is one of the most abundant biopolymers on earth and is an important structural component of the plant cell wall (Forsberg et al., 1997). Ruminants have developed a unique microbial symbiosis in the foregut (rumen) to utilize this plant tissue (Hungate, 1984), but fermentable fibre can often be recovered from the faeces (Beever et al., 1972; Ulyatt \& MacRae, 1974). Therefore, it can be hypothesized that the microbial population in the rumen is limiting. The view is often put forward that the physical and chemical properties of bacterial cellulases and hemicellulases (e.g. specific activity), or the number of highly cellulolytic bacteria, may limit digestion (Forsberg et al., 1997). These, or similar reasons, are often used to justify research on recombinant

Abbreviations: BCVFA, branched-chain volatile fatty acids; DDMI, digestible dry matter intake; DMD, dry matter digestibility; DMI, dry matter intake; TCC, total culturable count. cellulolytic ruminal bacteria (Weimer, 1996; Forsberg et al., 1997). However, few in vivo experiments have examined the feasibility of this approach by giving due consideration to the inherent ecological and physiological constraints imposed upon fibre digestion by the rumen ecosystem.

The observations that faeces may contain potentially fermentable fibre were supported by the work of Van Gylswyk (1970), who demonstrated that nutritional inadequacy could limit ruminal fibre fermentation. Ruminococcus (one of the most fibrolytic rumen bacteria; Hespell et al., 1997) numbers were increased when poor quality forage was supplemented with urea and branched-chain volatile fatty acids (BCVFA). There was an associated improvement in feed intake and some improvement in forage digestibility, a result which suggested that the abundance of fibrolytic bacteria in the rumen was limiting cell-wall digestibility (Van Gylswyk, 1970). In contrast, Dehority \& Tirabasso (1998) increased the numbers of fibrolytic bacteria in the rumen 
by feeding a high-cellulose diet composed of purified wood cellulose. There was a 10 -fold increase in the number of cellulolytic bacteria, but no significant increase in the digestion of alfalfa (lucerne) cellulose when it was placed in a nylon bag and suspended in the rumen for $24 \mathrm{~h}$.

If fibre digestibility is to be improved by microbial manipulation, then two questions need to be answered. The first is whether it is the cellulolytic bacteria or the actual nature of plant cell walls that are the limiting factor to improving fibre digestion. A second, and very significant, issue is whether introduced organisms can multiply and persist at levels in the rumen that are sufficient to improve fibre digestion. To address these questions, we increased the relative abundance of highly fibrolytic Ruminococcus by daily dosing over a period of $8 \mathrm{~d}$. Introduced strains of ruminal bacteria often decline rapidly after dosing (Flint et al., 1989; Miyagi et al., 1995; Attwood et al., 1988), making it difficult to measure the effect of the dosed strains on fibre digestion. We hoped that our protocol would enable us to measure fibre digestion in the presence of high numbers of dosed strains and that repeated dosing would enable inoculants to establish in the rumen.

We designed and characterized unique 16S-rRNA-based oligonucleotide probes to each of the dosed strains in order to track these organisms in the rumen. In addition, we used higher-level probes to Ruminococcus, Fibrobacter and eukaryotes to explore the effects of dosing on these populations. Various physiological parameters of fibre digestion [in situ nylon bag digestibility, wholetract dry matter digestibility (DMD), dry matter intake (DMI) and digestible dry matter intake (DDMI)] were used to measure fibrolytic activity in the rumen.

\section{METHODS}

General. Two separate animal experiments were conducted with adult sheep fitted with rumen cannulas (McSweeney, 1989). In experiment 1 , six sheep (three sheep in each of the dosed and control groups) were fed at $80 \%$ of ad libitum intake and feed was dispensed with an automatic feeder which divided the daily ration into eight equal portions fed at $3 \mathrm{~h}$ intervals. Rumen samples were collected for measurement of microbiological (culturable and molecular) and functional parameters of fibre degradation in vitro. Measurements of in situ nylon bag digestibility, DMI and DDMI were also made. In experiment 2 , ten sheep were included in each of the control and dosed groups, but only measurements of whole-tract DMI, DMD and DDMI were made. These animals were fed on an ad libitum basis and there was a slight difference in the dosing protocol (see below). Animals in both experiments were fed a daily ration of low-quality rhodes grass (Chloris gayana; $4.4 \%$ crude protein), supplemented with minerals (Fermafos; Rumevite) and cotton seed meal (100 g; 37\% crude protein).

\section{Housing and feeding}

Experiment 1. Adult Merino sheep (30-35 kg) were maintained in individual metabolism crates in a containment animal house. Six sheep divided into dosing and control groups were housed in metabolism cages in separate rooms. The two groups were completely isolated from one another (separate feed and water supply and ventilation system) to prevent contamination of controls by dosed sheep. Dosing and sample collection was always carried out on control animals first, followed by the dosed animals.

In situ nylon bag DMD was only measured in experiment 1 and during the last $24 \mathrm{~h}$ of each of the pre-dosing, dosing and post-dosing periods. Air-dried rhodes grass was ground through a $2 \mathrm{~mm}$ mesh screen and $3 \mathrm{~g}$ was weighed into a Dacron bag $(19 \times 9.5 \mathrm{~cm}$, pore size $50 \mu \mathrm{m})$. A single steel marble was inserted and the bag tied off before being suspended in the rumen. Bags were removed from the rumen and washed together with the control bag (not suspended in the rumen) in water while gently squeezing until no colour was visible in the wash. Bags were then dried at $65^{\circ} \mathrm{C}$ and in situ nylon bag digestibility determined by difference.

Experiment 2. Ten adult cannulated sheep were used in the control and dosed groups. The number of animals was greater than that in experiment 1 to increase the possibility of obtaining statistically significant results for DMI, DMD and DDMI. Rotary feeders were not used and animals received feed ad libitum. Diets were identical to those in experiment 1.

Sheep were fitted with rubber rings glued to wool around the anus to allow attachment of faecal collection bags (Raabe, 1968). Total faecal collections were made for $10 \mathrm{~d}$, after a training period of 2 weeks to accustom sheep to the diet and daily faecal collection procedures. There were three intake and collection periods of $10 \mathrm{~d}$ each, designated pre-dosing, dosing and post-dosing. During the dosing period, sheep were dosed daily (500 $\mathrm{ml}$ of dose) through the rumen fistula, and feed was immediately offered to provide 150-200 g in excess of the amount eaten during the previous day. Calculations of DDMI and DMI were made during the three periods and data from days 1 and 2 of each period were excluded to allow for adaptation to treatment. Total faecal output was collected from each sheep for each period, dried at $65^{\circ} \mathrm{C}$ for $48 \mathrm{~h}$ and weighed. DMI was calculated as the total intake of rhodes grass corrected for feed refusal and wastage.

Medium composition. Basal medium composition was (per litre) : $150 \mathrm{ml}$ clarified rumen fluid, $150 \mathrm{ml}$ mineral solution A (contents per $100 \mathrm{ml}: 3 \mathrm{~g} \mathrm{~K}_{2} \mathrm{HPO}_{4} \cdot 3 \mathrm{H}_{2} \mathrm{O}$ ), $150 \mathrm{ml}$ minerals solution $\mathrm{B}$ (contents per $100 \mathrm{ml}: 3 \mathrm{~g} \mathrm{KH}_{2} \mathrm{PO}_{4}, 6 \mathrm{~g}\left(\mathrm{NH}_{4}\right)_{2} \mathrm{SO}_{4}$, $\left.6 \mathrm{~g} \mathrm{NaCl}, 1.23 \mathrm{~g} \mathrm{MgSO}_{4} .7 \mathrm{H}_{2} \mathrm{O}, 1.58 \mathrm{~g} \mathrm{CaCl}_{2} .2 \mathrm{H}_{2} \mathrm{O}\right), 2 \mathrm{ml}$ trace mineral salts [contents per $100 \mathrm{ml}: 0.5 \mathrm{mg} \mathrm{ZnSO}{ }_{4} .7 \mathrm{H}_{2} \mathrm{O}$, $0.15 \mathrm{mg} \mathrm{MnCl}_{2} .4 \mathrm{H}_{2} \mathrm{O}, 1.5 \mathrm{mg} \mathrm{H} \mathrm{BO}_{3}, 1.0 \mathrm{mg} \mathrm{CoCl}{ }_{2} .6 \mathrm{H}_{2} \mathrm{O}$, $0.05 \mathrm{mg} \quad \mathrm{CaCl}_{2} .2 \mathrm{H}_{2} \mathrm{O}, \quad 0.1 \mathrm{mg} \quad \mathrm{NiCl}_{2} . \mathrm{H}_{2} \mathrm{O}, \quad 0.15 \mathrm{mg}$ $\left.\mathrm{Na}_{2} \mathrm{MO}_{4} \cdot 2 \mathrm{H}_{2} \mathrm{O}, 7 \cdot 5 \mathrm{mg} \mathrm{FeCl} \cdot 4 \mathrm{H}_{2} \mathrm{O}\right), 3 \cdot 1 \mathrm{ml}$ volatile fatty acid solution (contents per $100 \mathrm{ml}: 0.68 \mathrm{ml}$ acetic acid, $0.3 \mathrm{ml}$ propionic acid, $0.18 \mathrm{ml}$ butyric acid, $0.05 \mathrm{ml}$ isobutyric acid, $0.06 \mathrm{ml}$ methylbutyric acid, $0.06 \mathrm{ml}$ valeric acid, $0.06 \mathrm{ml}$ isovaleric acid, $0 \cdot 1 \mathrm{~g}$ phenylacetic acid), $1 \mathrm{~g} \mathrm{~L}$-cysteine. $\mathrm{HCl}$ and $0.01 \%$ resazurin. Media were prepared anaerobically according to the methods of Hungate (1950) as modified by Bryant (1972). The anaerobic gas was a $95 \% \mathrm{CO}_{2}: 5 \% \mathrm{H}_{2}$ mix, and $4 \mathrm{~g} \mathrm{Na}_{2} \mathrm{CO}_{3} \mathrm{l}^{-1}$ was included to buffer the medium at $\mathrm{pH} 6.7$. Aliquots $(9 \mathrm{ml})$ of anaerobically prepared medium were dispensed into $25 \mathrm{ml}$ Balch tubes $(18 \mathrm{~mm} \times 250 \mathrm{~mm})$ inside the anaerobic cabinet, stoppered and autoclaved for $15 \mathrm{~min}$ at $100 \mathrm{kPa}$. Medium for enumeration of total culturable counts (TCC) contained in addition to the basal medium (per litre): $150 \mathrm{ml}$ clarified rumen fluid (total of $300 \mathrm{ml}), 20 \mathrm{ml}$ DL-lactic acid $(10 \%, \mathrm{v} / \mathrm{v}), 0.4 \mathrm{~g}$ Casitone, $0.4 \mathrm{~g}$ cellobiose, $0.4 \mathrm{~g}$ soluble starch, $0.4 \mathrm{~g}$ maltose, $0.4 \mathrm{~g}$ birchwood xylan and $2 \cdot 0 \mathrm{~g}$ agar. Anaerobic diluent was made up as described previously (Mackie \& Wilkens, 1988). 
Cultures used for dosing. Strains of Ruminococcus albus (SY3 and AR67) and Ruminococcus flavefaciens (Y1, LP9155 and AR72) were selected for dosing based on their superior ability to degrade dry matter and neutral detergent fibre of two tropical grasses [rhodes grass and spear grass (Heteropogon contortus)] and a temperate legume [lucerne (Medicago sativa)]. These were laboratory strains that had been in culture for at least 3 years. Their ability to degrade purified cellulose was also evaluated (Krause et al., 1999a).

Preparation of Ruminococcus spp. for dosing. Ruminococcus strains used for dosing were maintained as axenic cultures on basal medium plus $50 \mathrm{mg}$ rhodes grass (in $10 \mathrm{ml}$ medium) for at least 2 weeks to ensure that they were growing well on the same complex carbohydrate sources as fed to sheep. Medium for dosing was made up anaerobically in 21 bottles and contained basal medium plus $10 \mathrm{~g}$ rhodes grass. In experiment 1 , Ruminococcus strains were inoculated into the same 21 medium bottle in an anaerobic chamber and were allowed to incubate at $39^{\circ} \mathrm{C}$ for $24 \mathrm{~h}$, at which time $0 \cdot 1 \%$ cellobiose was added to the medium. Bacteria were allowed to grow for an additional $24 \mathrm{~h}$ before dosing to sheep. Growth before the addition of cellobiose ensured that rhodes grass would be utilized, while growth on cellobiose increased cell yield. In experiment 2, the individual Ruminococcus strains were always grown separately, and were mixed together in an anaerobic cabinet immediately prior to dosing.

Sheep (experiments 1 and 2) were dosed with $500 \mathrm{ml}$ medium containing the designated Ruminococcus strains. Control sheep received $500 \mathrm{ml}$ fresh uninoculated medium. Direct microscopic counts indicated that Ruminococcus grew to approximately $1 \times 10^{10}$ cells $\mathrm{ml}^{-1}$ (estimated from direct microscopic counts of several doses), so that each animal received approximately $5 \times 10^{12}$ cells. Sheep were dosed consecutively for $9 \mathrm{~d}, 1 \mathrm{~h}$ after the morning feeding. Representative rumen digesta samples (approx. $100 \mathrm{~g}$ ) were taken with a stomach tube (20 $\mathrm{mm}$ diameter) immediately prior to dosing, placed on ice and transported to the laboratory for further processing (only experiment 1).

Enumeration of TCC. Ten grams of rumen digesta was weighed out into a $300 \mathrm{ml}$ beaker and diluted $(1: 10)$ with chilled anaerobic diluent. This mixture was blended for $1 \mathrm{~min}$ (Bamix) and serially diluted to the $10^{-10}$ dilution (Mackie \& Wilkens, 1988). Droplets $(20 \mu \mathrm{l})$ were pipetted onto TCC plates in an anaerobic chamber from the $10^{-5}$ to $10^{-9}$ dilutions. Plates were incubated for approximately $48 \mathrm{~h}$ before colonies were counted.

RNA extraction. RNA was extracted according to the procedure of Stahl et al. (1988) with some modifications. A $1 \mathrm{ml}$ subsample of crude rumen digesta was taken with a wide-bore pipette $(5 \mathrm{~mm})$ so that sufficient plant material was included in the sample. The sample was pipetted into a $2 \mathrm{ml}$ screw-cap tube containing $0.5 \mathrm{~g}$ zirconium beads $(75-200 \mu \mathrm{m}$ diameter). The tube was centrifuged at $10000 \mathrm{~g}$ for $1 \mathrm{~min}$ to pellet digesta, the supernatant was discarded and $700 \mu \mathrm{l}$ phenol/ chloroform (4:1, pH 5.1) was added. Mechanical disruption of microbial biomass was done by bead-beating (Biospec) for 5 min. The nucleic acid was precipitated with a one-tenth volume of sodium acetate $(3 \mathrm{M})$, resuspended in RNase-free water and incubated at $39^{\circ} \mathrm{C}$ with $1 \mu \mathrm{g} \mathrm{ml} l^{-1}$ (final concentration) RNase-free DNase (Promega) to remove contaminating RNA. The RNA concentration was measured spectrophotometrically at $260 \mathrm{~nm}$ and adjusted to a final concentration of $100 \mathrm{ng} \mathrm{ll}^{-1}$. At least two subsamples from each sample of ruminal digesta were extracted and pooled.
Probe hybridization protocol. Oligonucleotides were labelled with digoxigenin (Roche Diagnostics) and analysis was carried out as previously described (Krause \& Russell, 1996). RNA was denatured by incubation for $10 \mathrm{~min}$ at $25^{\circ} \mathrm{C}$ with 3 vols $2 \%$ glutaraldehyde. A sample volume equivalent to $1 \mu \mathrm{g}$ per slot was diluted with $0 \cdot 0002 \%$ bromophenol blue and $1 \mu \mathrm{g}$ polyadenylic acid $\mathrm{ml}^{-1}$ before application to positively charged nylon membranes (Roche Diagnostics). The membranes were baked at $120^{\circ} \mathrm{C}$ for 30 min to covalently crosslink the rRNA to the membrane. Prehybridization solution [ $25 \%$ formamide, $5 \times$ SSC $(1 \times$ SSC: $0 \cdot 15 \mathrm{M}$ sodium chloride and 0.015 sodium citrate), $50 \mathrm{mM} \mathrm{Na}{ }_{2} \mathrm{HPO}_{4}, 2 \%$ blocking reagent (Roche Diagnostics), 2\% SDS, 0.1\% N-lauroylsarcosine] was incubated with membranes for at least $2 \mathrm{~h}$ before the addition of the labelled probe $\left(10 \mathrm{ng} \mathrm{ml}^{-1}\right)$. Probes were allowed to hybridize overnight and membranes were then washed at the appropriate stringency for each probe with $1 \times$ SSC. Membranes were subsequently processed according to the manufacturer's instructions (Roche Diagnostics). Total $16 \mathrm{~S}$ rRNA was determined by hybridization with a universal eubacterial probe. To prevent contamination, pre-dosing samples from the dosed sheep and all the samples from the control sheep were blotted onto separate membranes. Blotting was done in duplicate, with each duplicate blotted onto a separate membrane. A dilution series of the reference organism was included on the membrane with the samples or alternatively the dilution series was done on a membrane with only selected samples and then cross-referenced to the master membrane.

Optimization of wash temperature. Denatured RNA samples (1000 ng) were applied by slot-blotting to positively charged nylon membranes (Roche Diagnostics) and hybridized as described above. After hybridization, the membranes were cut into individual slots and each membrane (consisting of duplicate hybridization slots) was washed in $1 \times$ SSC for at least $10 \mathrm{~min}$ at $34^{\circ} \mathrm{C}$. This process was repeated 12 times at increasing temperatures $(34,37,40,43,46,49,52,55,58,61$, 63 and $\left.65^{\circ} \mathrm{C}\right)$. Each membrane was then processed as described above. The hybridization intensity (probe remaining on blot) was plotted against the wash temperature and the dissociation temperature $\left(T_{\mathrm{d}}\right)$ was defined as the temperature at which $50 \%$ of the duplex remained bound.

Cross-hybridization assay. Probes to the dosed ruminococci were synthesized and tested for specificity against a phylogenetically diverse group of ruminal bacteria. These bacteria included $R$. flavefaciens AR71, $R$. flavefaciens AR72, $R$. flavefaciens R13e2, R. flavefaciens LP-9155, R. flavefaciens $\mathrm{RF} 1 \mathrm{Ba}, R$. flavefaciens R1-addax, $R$. flavefaciens C14-addax, $R$. flavefaciens AR69, R. flavefaciens B146, R. flavefaciens AR46, R. flavefaciens AR47, R. flavefaciens Y1, R. flavefaciens FD-1, R. albus B199, R. albus Ra8, R. albus AR67, R. albus SY3, Ruminococcus callidus ATCC 27760, Ruminococcus bromii ATCC 27255, Butyrivibrio fibrisolvens OB156, B. fibrisolvens $\mathrm{H} 17 \mathrm{c}$, Escherichia coli K-12, Eubacterium cellulosolvens 5494, Eubacterium ruminantium GA195, Fibrobacter succinogenes S85, Lactobacillus vitulinus $\mathrm{B}_{2} 6$, Megasphaera elsdenii B159, Prevotella ruminicola 23, Prevotella ruminicola GA33, Ruminobacter amylophilus 70, Selenomonas ruminantium HD4, Streptococcus bovis JB1, Streptococcus bovis K11-21-09, Succinimonas amylolytica $\mathrm{B}_{2} 4$, Succinivibrio dextrinosolvens 22B, Treponema bryantii $\mathrm{B}_{2} 5$.

Statistical analysis. Experiments followed a repeated-measures factorial arrangement of treatments (dosed animal group and one control group) and time (levels) (Littell et al., 1998). Total sums of squares were partitioned between the sums of squares for treatments and time (level). Only F-values for 
model effects with an alpha-value greater than $0 \cdot 1$ were considered significant. The standard error of the mean (SEM) was computed for each analysis. All statistical analyses were carried out with Statistica 5.0 (StatSoft, Tulsa, USA).

\section{RESULTS}

\section{Specificity of oligonucleotide probes}

For each oligonucleotide probe, an experimental $\left(T_{\mathrm{d}}\right)$ and actual $\left(T_{\mathrm{e}}\right)$ dissociation wash temperature is presented (Table 1 ). The amount of probe remaining bound to the nylon membrane had a sigmoid shape as the wash temperature increased (Fig. 1). The temperature at which $50 \%$ of the probe was washed off the membrane was defined as the $T_{\mathrm{d}}$, and was $46 \cdot 3,58 \cdot 1,43 \cdot 8,56 \cdot 7$ and $46{ }^{\circ} \mathrm{C}$ for Ruminococcus strains SY3, AR67, Y1, LP9155 and AR72, respectively. However, in actual hybridization studies of ruminal samples, a compromise between specificity and sensitivity had to be made and the temperatures under experimental conditions were 50, 55, 46, 53 and $45^{\circ} \mathrm{C}$ for strains SY3, AR67, Y1, LP9155 and AR72, respectively (Table 1, Fig. 1).

Computer searches were made of oligonucleotide probes in GenBank and the closest small-subunit rRNA comparisons are shown in Table 2. S-Ss-Ralb SY3-0141-a-A20 was homologous to $R$. albus OR108 and there were no other close matches. S-Ss-Ralb AR67-1214-a-A-23 had no homologues and there were no close $16 \mathrm{~S}$ rDNA matches. S-Ss-Rflav Y1-0169-a-A-18 was $100 \%$ similar to B. fibrisolvens LP1265 and had four mismatches with the unidentified rumen bacterial clone RF4. S-Ss-RflavLP9155-0160-a-A-28 was homologous to $R$. flavefaciens NJ and had one mismatch with the unidentified rumen bacterial clone 4C0d-11; the next closest

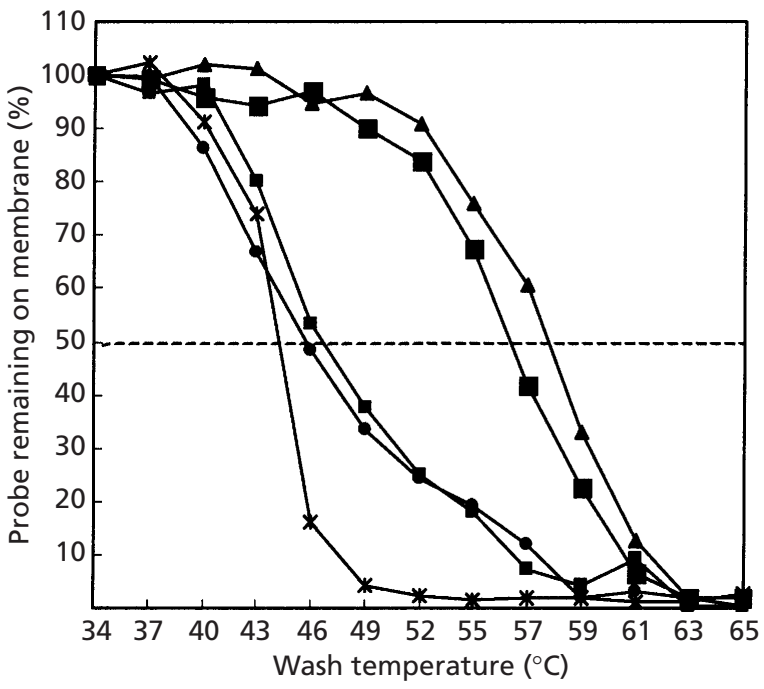

Fig. 1. Melting curves and dissociation temperatures $\left(T_{d}\right)$ for probes targeting strains SY3 (small squares), AR67 (triangles), LP9155 (large squares), Y1 (crosses) and AR72 (circles).

match was with clone 4C0d-7 (10 mismatches). S-SsRflav AR72-0186-a-A-18 was not $100 \%$ similar to any database sequence but had a 1 bp mismatch with $R$. flavefaciens strains FD-1, LP9155 and 4. There was also a 1 bp mismatch with clone AY006604 (GenBank accession number) and 'Clostridium phytofermentans' ISDg.

Probes were hybridized with a phylogenetically diverse group of ruminal bacteria, as well as rRNA extracted from rumen fluid. All probes were reasonably specific,

Table 1. 16S-rRNA-based oligonucleotide probes used in this study

\begin{tabular}{|c|c|c|c|c|c|}
\hline Target & Oligonucleotide $\uparrow$ & Sequence $\left(5^{\prime}-3^{\prime}\right)$ & $T_{\mathrm{e}} \ddagger$ & $T_{\mathrm{d}} \ddagger$ & Reference \\
\hline R. albus SY3 & S-Ss-RalbSY3-0142-a-A-20 & GATAAGCCGCATGACCTATC & 50 & $46 \cdot 3$ & This study \\
\hline R. albus AR67 & S-Ss-Ralb AR67-1213-a-A-23 & GGGTAGCAAAGTGGTGACACGGA & 55 & $58 \cdot 1$ & This study \\
\hline R. flavefaciens $\mathrm{Y} 1$ & S-Ss-Rflav Y1-0189-a-A-18 & GAGACCGCATGATTTCTG & 46 & $43 \cdot 8$ & This study \\
\hline R. flavefaciens LP9155 & S-Ss-Rflav LP9155-0128-a-A-28 & CGGAGATATTTTGGTTTACTGAGATATC & 53 & $56 \cdot 7$ & This study \\
\hline R. flavefaciens AR72 & S-Ss-Rflav AR72-0193-a-A-18 & CCGCATGATTTAGCTATC & 45 & $46 \cdot 0$ & This study \\
\hline$R$. albus $+R$. flavefaciens & S-G-Rum IV-0132-a-A-17 & TGKTAATACCYCATAAY & 33 & $33 \cdot 0$ & $\begin{array}{l}\text { Krause et al. } \\
(1999 \text { b) }\end{array}$ \\
\hline F. succinogenes & S-S-Fsucc-0650-a-A-20 & TGCCCCTGAACTATCCAAGA & 48 & 48 & $\begin{array}{l}\text { Lin et al. } \\
\text { (1994) }\end{array}$ \\
\hline Most bacteria & S-D-Bact-0338-a-A-18 & GCTGCCTCCCGTAGGAGT & 54 & 54 & $\begin{array}{l}\text { Amann et al. } \\
\text { (1990) }\end{array}$ \\
\hline Eukaryotes & S-D-Euka-1379-a-A-16 & TACAAAGGGCAGGGAC & 33 & 33 & $\begin{array}{l}\text { Hicks et al. } \\
\text { (1992) }\end{array}$ \\
\hline Most organisms & S-*-Univ-1390-a-A-18 & GACGGGCGGTGTGTACAA & 44 & 44 & $\begin{array}{l}\text { Zheng et al. } \\
\text { (1996) }\end{array}$ \\
\hline
\end{tabular}

† Probe nomenclature according to Oligonucleotide Probe Database (Alm et al., 1996).

¥Wash temperature for slot-blot probes. $T_{\mathrm{e}}$ is the actual experimental wash temperature used in these experiments, and $T_{\mathrm{d}}$ is the experimentally determined wash temperature. Post-hybridization washes for slot-blotting were done with $1 \times$ SSC $(0 \cdot 15 \mathrm{M}$ sodium chloride plus 0.015 sodium citrate). 
Table 2. Comparison of oligonucleotide probes and their target small-subunit ribosomal rRNA sequences available from GenBank

\begin{tabular}{|c|c|c|c|c|}
\hline Probe and target bacterium & $\begin{array}{l}\text { Bacterial } \\
\text { strain }\end{array}$ & $\begin{array}{l}5^{\prime} \text { position } \\
\text { of target }\end{array}$ & $\begin{array}{l}\text { Probe and complementary target } \\
\text { sequence }\left(5^{\prime}-3^{\prime}\right)^{*}\end{array}$ & $\begin{array}{l}3^{\prime} \text { position } \\
\text { of target }\end{array}$ \\
\hline S-Ss-Ralb SY3-0141-a-A-20 & & & GATAAGCCGCATGACCTATC & \\
\hline Ruminococcus albus & SY3 & 141 & GATAAGCCGCATGACCTATC & 160 \\
\hline Ruminococcus albus & OR108 & 174 & GATAAGCCGCATGACCTATC & 193 \\
\hline S-Ss-Ralb AR67-1214-a-A-23 & & & GGGTAGCAAAGTGGTGACACGGA & \\
\hline Ruminococcus albus & AR67 & 1214 & GGGTAGCAAAGTGGTGACACGGA & 1236 \\
\hline S-Ss-Rflav Y1-0169-a-A-18 & & & GAGACCGCATGATTTCTG & \\
\hline Ruminococcus flavefaciens & Y1 & 169 & GAGACCGCATGATTTCTG & 186 \\
\hline Butyrivibrio fibrisolvens & LP1265 & 158 & GAGACCGCATGATTTCTG & 175 \\
\hline Unidentified rumen bacterium & RF4 & 134 & ...АCCGCATGATTTCT. & 151 \\
\hline S-Ss-Rflav LP9155-0060-a-A-28 & & & CGGAGATATTTTGGTTTACTGAGATATC & \\
\hline Ruminococcus flavefaciens & LP9155 & 60 & CGGAGATATTTTGGTTTACTGAGATATC & 87 \\
\hline Ruminococcus flavefaciens & $\mathrm{NJ}$ & 60 & CGGAGATATTTTGGTTTACTGAGATATC & 87 \\
\hline Unidentified rumen bacterium & $4 \mathrm{C} 0 \mathrm{~d}-11$ & 13 & CGGAGATATTTTGGTTTACTGAG. TATC & 40 \\
\hline Unidentified rumen bacterium & $4 \mathrm{C} 0 \mathrm{~d}-7$ & 67 & ......АTTTTGGTTTACTGAGAT. . & 94 \\
\hline S-Ss-Rflav AR72-0186-a-A-18 & & & CCGCATGATTTAGCTATC & \\
\hline Ruminococcus flavefaciens & AR72 & 186 & CCGCATGATTTAGCTATC & 203 \\
\hline Unidentified rumen bacterium & AY006604 & 175 & CCGCATGATTT.GCTATC & 192 \\
\hline Ruminococcus flavefaciens & FD-1 & 155 & CCGCATGATTTAG. TATC & 173 \\
\hline Ruminococcus flavefaciens & LP9155 & 183 & CCGCATGATTTAG.TATC & 200 \\
\hline Ruminococcus flavefaciens & 4 & 181 & CCGCATGATTTAG. TATC & 198 \\
\hline 'Clostridium phytofermentans' & ISDg & 97 & CCGCATGATTT.GCTATC & 117 \\
\hline
\end{tabular}

*16S rDNA oligonucleotide probe sequence and matching rRNA sequence in GenBank are given. Stops indicate mismatches.

but all cross-reacted with rRNA extracted from control animals. However, the signal intensity in the dosed animals was sufficiently large to enable the tracking of dosed strains. When probes were hybridized with rRNA from individual strains cross-reactivity occurred. Probes to AR72 and LP9155 had 1 bp mismatches in comparison to their closest GenBank matches, and crossreacted with AR71, and with AR64 and AR47, respectively. Probes to SY3 and AR67 were unique and no cross-reactivity with individual strains was detected.

One-quarter dilutions were made of $1000 \mathrm{ng}$ rRNA extracted from strains SY3, AR67, Y1, LP9155 and AR72, and blotted onto nylon membranes. Hybridization with probes to SY3, AR67, Y1, LP9155 and AR72 indicated that as little as $0.9 \mathrm{ng} 16 \mathrm{~S}$ rRNA could be detected (Fig. 2). This value constituted approximately $10^{6}$ cells $\mathrm{ml}^{-1}$ and represented the probe detection limit.

\section{Estimation of the relative abundance of different groups of bacteria}

The relative abundance of individual strains increased during dosing and peaked at $\sim 1 \cdot 9,0.8$ and $1.8 \%$ for $R$. flavefaciens strains Y1, AR72 and LP9155, respectively (Fig. 3a). The levels of $R$. albus strains SY3 and AR67 peaked at $\sim 1.7$ and $1.2 \%$, respectively (Fig. 3b). The effect of dosing was significant $(P<0.05$ for Y1, LP9155,

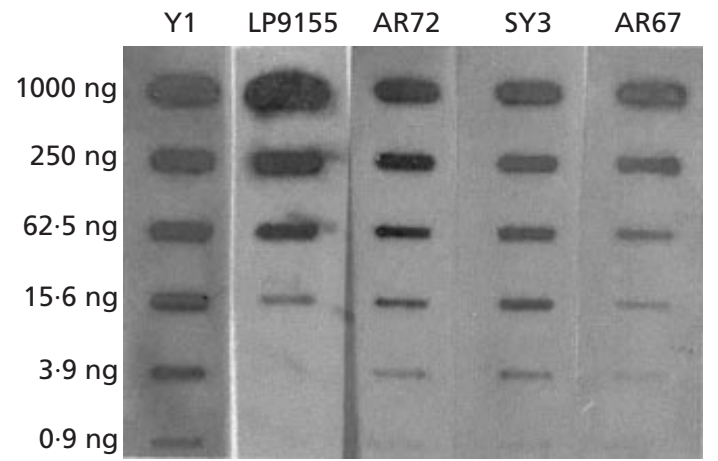

Fig. 2. One-quarter dilution series of rRNA extracted from strains SY3, AR67, LP9155, Y1 and AR72, hybridized with complementary probe and washed with $1 \times$ SSC at experimental wash temperatures ( $T_{\mathrm{e}}$; see Table 1$)$.

SY3 and AR67, and $P<0 \cdot 1$ for AR72) for all strains, and many time-point comparisons during the dosing and post-dosing periods were significant $(P<0 \cdot 05)$. All five strains were grown together immediately prior to dosing and rRNA slot-blot analysis of the dose showed that the relative abundance of strains LP9155, Y1, SY3, AR67 and AR72 were $20( \pm 1 \cdot 0), 19( \pm 2 \cdot 0), 16( \pm 2 \cdot 0), 9$ $( \pm 0.8)$ and $6( \pm 0.7) \%$, respectively, of the total dose.

An oligonucleotide probe specific for most $R$. albus and 

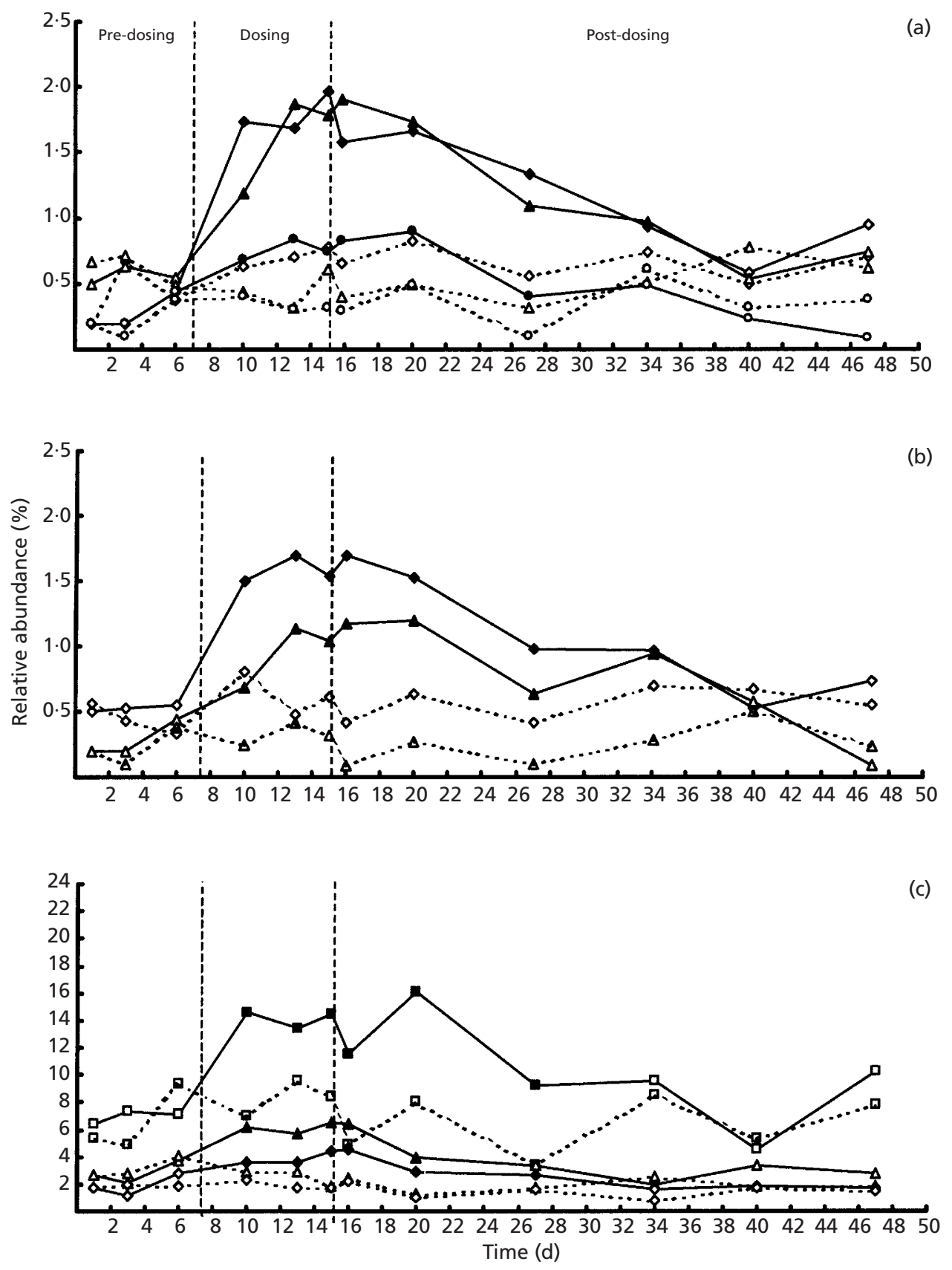

(d)

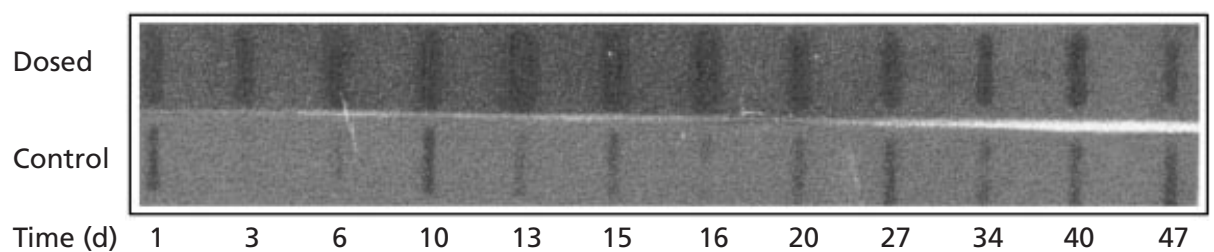

Fig. 3. (a-c) Small-subunit-rRNA-based relative abundances of specific organisms, or groups of organisms, in sheep dosed with Ruminococcus. $(a, b)$ Relative abundance as a proportion of the total bacterial population for dosed $R$. flavefaciens strains Y1 (diamonds), LP9155 (triangles) and AR72 (circles) (a); and R. albus strains SY3 (diamonds) and AR67 (triangles) (b). (c) Total Ruminococcus (triangles) and Fibrobacter (diamonds) as a proportion of the bacterial population, and eukaryotes (squares) as a proportion of the total microbial population. In each panel (a,b or c), dotted lines represent undosed control animals and solid lines represent dosed animals; open symbols represent controls and values not significantly different $(P>0.05)$ from controls; solid symbols represent values significantly different $(P<0.05)$ from controls. (d) Typical hybridization results for an animal dosed with strains of ruminococci in comparison to an undosed control. 


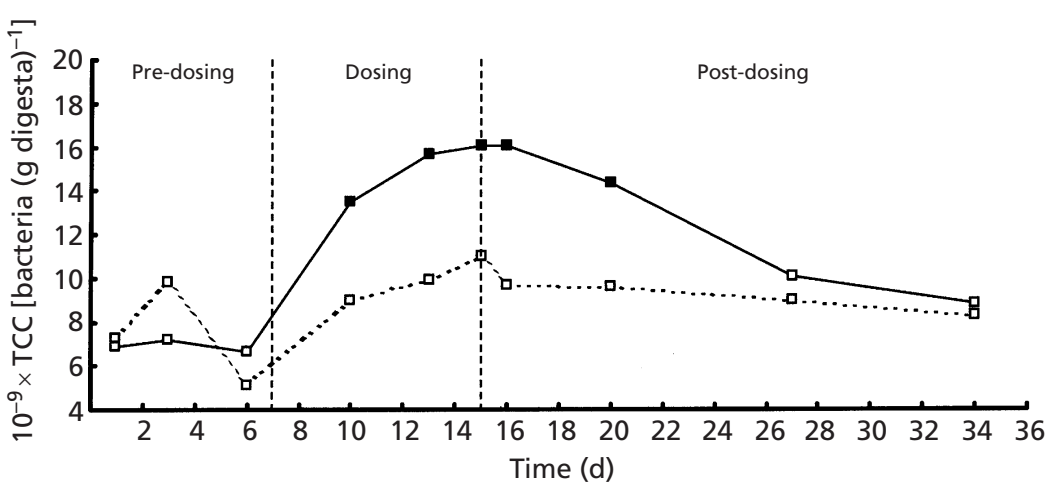

Fig. 4. Enumeration of the TCC. The dotted line represents undosed control animals and the solid line represents dosed animals; open symbols represent controls and values not significantly different $(P>0.05)$ from controls; solid symbols represent values significantly different $(P<0.05)$ from controls.

Table 3. Intake and in situ nylon bag digestibility values of sheep dosed with Ruminococcus spp. in experiment 1

\begin{tabular}{|c|c|c|c|}
\hline \multirow[t]{2}{*}{ Period } & \multicolumn{2}{|c|}{ Treatments } & \multirow[t]{2}{*}{ SEM" } \\
\hline & Control & Dosed & \\
\hline \multicolumn{4}{|c|}{ DMI $\left(\mathrm{g} \mathrm{d}^{-1}\right)$} \\
\hline Pre-dosing & $693 \cdot 7$ & $676 \cdot 1$ & $43 \cdot 7$ \\
\hline Dosing & $794 \cdot 1$ & $793 \cdot 0$ & $64 \cdot 9$ \\
\hline Post-dosing & $748 \cdot 4$ & $797 \cdot 5$ & $71 \cdot 4$ \\
\hline \multicolumn{4}{|c|}{ In situ nylon bag digestibility (\%) } \\
\hline Pre-dosing & $34 \cdot 7$ & $33 \cdot 9$ & $1 \cdot 5$ \\
\hline Dosing & $36 \cdot 8$ & $35 \cdot 7$ & $0 \cdot 9$ \\
\hline Post-dosing & $36 \cdot 7$ & $36 \cdot 7$ & $1 \cdot 4$ \\
\hline \multicolumn{4}{|c|}{$\operatorname{DDMI}\left(\mathrm{g} \mathrm{d}^{-1}\right)$} \\
\hline Pre-dosing & $240 \cdot 7$ & $229 \cdot 2$ & $16 \cdot 5$ \\
\hline Dosing & $292 \cdot 2$ & $283 \cdot 1$ & $26 \cdot 4$ \\
\hline Post-dosing & $274 \cdot 6$ & $292 \cdot 7$ & $27 \cdot 7$ \\
\hline$n \dagger$ & 3 & 3 & \\
\hline
\end{tabular}

* Pooled standard error of the mean. Means were not significant at the $P<0 \cdot 1$ or $P<0 \cdot 05$ levels.

† Number of animals used.

$R$. flavefaciens (Table 1) was used to monitor the total abundance of Ruminococcus. During the dosing period, ruminococci increased $(P<0.05)$ to approximately $6.5 \%$ of the total bacterial population, but declined to baseline levels by $19 \mathrm{~d}$ post-dosing (Fig. 3c). When the relative abundance of each individual dosed strain was summed, it correlated reasonably well $(r=0.58)$ with that determined using the genus-specific Ruminococcus probe. It is likely that cross-reactivity between probe and nonspecific target prevented a higher correlation from being obtained. When the F. succinogenes population size was estimated (Fig. 3c), there was an increase during the dosing period to approximately $4.7 \%$ of the total bacterial 16S rRNA population and the effect of dosing was statistically significant $(P<\cdot 05)$. The F. succinogenes population declined post-dosing in a manner similar to that of the ruminococci population. Eukaryote abundance also increased $(P<0 \cdot 1)$ during dosing but
Table 4. Intake and in situ nylon bag digestibility values of sheep dosed with Ruminococcus spp. in experiment 2

\begin{tabular}{|c|c|c|c|}
\hline \multirow[t]{2}{*}{ Period } & \multicolumn{2}{|c|}{ Treatments } & \multirow[t]{2}{*}{ SEM" } \\
\hline & Control & Dosed & \\
\hline \multicolumn{4}{|c|}{ DMI $\left(\mathrm{g} \mathrm{d}^{-1}\right)$} \\
\hline Pre-dosing & $768 \cdot 9$ & $800 \cdot 8$ & $48 \cdot 4$ \\
\hline Dosing & $820 \cdot 8$ & $850 \cdot 2$ & $67 \cdot 1$ \\
\hline Post-dosing & $863 \cdot 5$ & $860 \cdot 5$ & $73 \cdot 4$ \\
\hline \multicolumn{4}{|c|}{ In situ nylon bag digestibility (\%) } \\
\hline Pre-dosing & $46 \cdot 3$ & $46 \cdot 5$ & $1 \cdot 8$ \\
\hline Dosing & $45 \cdot 5$ & $45 \cdot 5$ & $1 \cdot 1$ \\
\hline Post-dosing & $46 \cdot 2$ & $46 \cdot 1$ & $1 \cdot 3$ \\
\hline \multicolumn{4}{|c|}{$\operatorname{DDMI}\left(\mathrm{g} \mathrm{d}^{-1}\right)$} \\
\hline Pre-dosing & $352 \cdot 1$ & $372 \cdot 2$ & $22 \cdot 6$ \\
\hline Dosing & $370 \cdot 1$ & $388 \cdot 1$ & $30 \cdot 2$ \\
\hline Post-dosing & $385 \cdot 7$ & $399 \cdot 4$ & $35 \cdot 6$ \\
\hline$n \dagger$ & 10 & 10 & \\
\hline
\end{tabular}

* Pooled standard error of the mean. Means were not significant at the $P<0 \cdot 1$ or $P<0 \cdot 05$ levels.

† Number of animals used.

was never greater than $16 \%$ of the total $16 \mathrm{~S}$ rRNA population (Fig. 3c).

During the dosing period, TCC increased significantly $(P<0.05)$ from approximately $7 \times 10^{9}$ to $1.6 \times 10^{10} \mathrm{ml}^{-1}$ (Fig. 4). This was an increase of $128 \%$ over that during the pre-dosing period. The increase in TCC was in general agreement with that of Fibrobacter and eukaryotic populations (Fig. 3c), which increased by approximately $100 \%$. In contrast, the Ruminococcus increased by almost $200 \%$ (Fig. 3c).

\section{Feed intake and in situ nylon bag digestibility}

When animals were dosed there was an insignificant $(P$ $>0.05$ ) increase in DMI in experiments 1 (Table 3 ) and 2 (Table 4). In situ nylon bag digestibility (experiment 1 , Table 3) and whole-tract DMD showed no differences 
between the control and dosed groups, but when digestibility was expressed as DDMI there appeared to be a slight, but insignificant $(P>0.05)$ increase postdosing (Tables 3 and 4).

\section{DISCUSSION}

Sequence variation of $16 \mathrm{~S}$ rDNA among closely related strains is not great (Fox et al., 1992), and we sequenced the 23S-16S intragenic region (Vinuesa et al., 1998; Sawada et al., 1997; Rijpens et al., 1996) of 16 R. albus and $R$. flavefaciens strains to see if this area could be used as an alternative region for probe design (D. O. Krause, data not shown). Unfortunately, the sequence variation was no greater than that of the hypervariable regions of $16 \mathrm{~S}$ rDNA. Probes were consequently derived from multiple alignments of $16 \mathrm{~S}$ rDNA genes from 33 strains of $R$. albus and R. flavefaciens. In some cases, sequence variation was not sufficient for design of unique probes (e.g. probes to strains SY3 and Y1, Table 2) and stringency conditions in hybridization studies were relaxed to increase the degree of sensitivity (Table 1). This resulted in some cross-hybridization with rRNA from control sheep and with non-target ruminal strains. The hybridization intensity was, however, greater than background, which enabled the strain-specific probes to be useful tools for assessing the ecology of fibre digestion.

Probes to SY3, AR67 and Y1 performed well and there was very little cross-hybridization with non-target strains. In comparison, probes to LP9155 and AR72 cross-reacted and probe design relied, in some cases, on only $1 \mathrm{bp}$ mismatches with non-target strains. A possible means of increasing probe specificity is the use of peptide nucleic acids (PNA), in which the sugar-phosphate backbone is replaced by peptide moieties (Nielsen, 1999; Von Wintzingerode et al., 2000). The stability of the PNA-DNA duplex is considerably greater than that of the RNA-DNA duplex (Nielsen, 1999).

Results from individual strain probes (Fig. 3a, b) showed that dosed organisms declined post-dosing, which is typical of dosing studies (Flint et al., 1989; Miyagi et al., 1995; Attwood et al., 1988), illustrating that ecological principles governing the persistence of bacterial inoculants in complex microbial communities are not well understood. It is, however, apparent that persistence is probably a consequence of community-level reproductive strategies in which community processes limit the relative abundance of individual organisms (Caldwell et al., 1997). These strategies are based on the evolution of cooperative networks of micro-organisms in which some members cleave specific bonds, others utilize particular substrates and still others produce inhibitors (Caldwell et al., 1997). A ruminal example is the production of cellodextrins by cellulolytic bacteria (Russell, 1985), which are utilized by non-structural carbohydrate-fermenting bacteria (NSC). The NSC in turn produce ammonia and BCVFA that are consumed by cellulolytic bacteria (Miller \& Wolin, 1979; Wolin \&
Miller, 1988). It is unlikely that the inability to produce cellodextins or the lack of a requirement for BCVFA are the reason that the dosed strains did not persist. However, the long time that these strains have been in culture, inhibition by bacteriocin-producing organisms (Odenyo et al., 1994a, b) and protozoal predation (Sharp et al., 1994) may be significant factors in thwarting their successful reproduction in the rumen.

Establishment of an exogenous organism in the rumen is complicated by the fact that the rumen is not a closed ecosystem and micro-organisms are continually entering, making it a dynamic system that significantly impacts on the persistence of the inoculant. This was demonstrated by Varel et al. (1995) who removed the rumen contents from three cows and replaced it with 201 medium buffer and 61 'Clostridium longisporum'. At the initiation of the experiment, ' $C$. longisporum' was the predominant cellulolytic bacterium, but it decreased to below the detection limit after $48 \mathrm{~h}$. In similar experiments in our laboratory (D. O. Krause \& C. S. McSweeney, unpublished) we grew R. albus AR67 in $20 \mathrm{l}$ fermenters containing a nutrient medium and rhodes grass. The rumen contents of cannulated cattle were completely removed and replaced by the fermenter contents. Animals were immediately allowed to consume a rhodes grass diet, but we found that gastric stasis was often the consequence and the dosed strain declined rapidly. The reasons for the decline are not known, but the predatory behaviour of protozoa may be significant (Coleman \& Sandford, 1979; Sharp et al., 1994; Newbold \& Hillman, 1990).

Recent data suggest that dosing of ruminococci while the rumen is still immature does not allow the establishment of the introduced strains of bacteria (Krause et al., 1999c). When rRNA from the rumen of lambs was hybridized with a probe to the small-subunit rDNA of eukaryotes, there was a significant increase in the relative abundance of eukaryotic rRNA in the dosed groups, implying that protozoal predation might have a significant effect on persistence. In the current study, we observed an increase in the eukaryotic population during dosing to approximately $16 \%$ of the $16 \mathrm{~S}$ rRNA population (Fig. 3c). In the non-dosed animals, eukaryotes ranged between approximately 3 and $9 \%$ (Fig. 3c). Direct observations of protozoal predation of the dosed strains in this study were not made, but in vitro experiments have shown that when a recombinant Lactobacillus plantarum was mixed with rumen fluid containing protozoa, the rate of decline of the recombinant bacterium was far greater than when the protozoa were absent (Sharp et al., 1994).

The increase in the eukaryote population may not have been specifically a predation response, but may simply have been a response to the nutrients present in the dose. The bacterial dose contained nitrogen (from bacteria) as well as fermentation acids, which have previously been shown to benefit ruminal fibre fermentation (Van Gylswyk, 1970). Lin et al. (1996), using a eukaryotic signature sequence (S-D-Euca-0502-a-A-16), probed rRNA extracted from rumen contents of animals con- 
suming diets which differed in the proportion of forage and concentrate. When animals were on a $100 \%$ forage diet, the eukaryotic population varied between 16.9 and $18.8 \%$ of the total population. If concentrate was included in the diet (at least $40 \%$ ), the eukaryotic population tended to decline.

The probe used to measure the increase in the eukaryote population will hybridize to rRNA from fungi as well as protozoa. Fungi are important inhabitants of the rumen and may make a significant contribution to fibre digestion (Hespell et al., 1997). In a previous study (Krause et al., 1999c), lambs were dosed with these same strains and we measured the fungal population separately from the eukaryotic populations. These data indicated that the fungal response to the dosing regimen was small in comparison to the total eukaryotic response. Future studies should design and validate 16Slike rRNA probes to ruminal protozoa so that this possibility can be examined specifically.

In dosed animals, the Ruminococcus population was as high as $6.5 \%$ and in the undosed group varied between 1.2 and $4.0 \%$ of the total bacterial population (Fig. 3c). $F$. succinogenes increased to $4.7 \%$ in dosed animals and was low as $0.9 \%$ of the bacterial population in control animals (Fig. 3c). Previous investigations with S-GRum IV-0132-a-A-17 and S-S-Fsucc-0650-a-A-20 have shown that Ruminococcus and F. succinogenes vary as a proportion of the bacterial population depending on the diet. When animals were fed a diet of $100 \%$ rhodes grass, Ruminococcus was $1 \cdot 3-1 \cdot 9 \%$ of the population and Fibrobacter $0.8-2.7 \%$ (Krause et al., 1999b). In contrast, if sheep were fed a diet of $30 \%$ Calliandra calothyrsus (tannin-rich) and $70 \%$ rhodes grass, Ruminococcus and Fibrobacter were less than $2 \%$ of the bacterial population (McSweeney et al. 2001). When these same animals were placed on a diet of $70 \%$ rhodes grass and 30\% lucerne (Medicago sativa) the populations rose to approximately $6 \%$ for both Ruminococcus and Fibrobacter. Lin et al. (1994), using S-SFsucc-0650-a-A-20, observed that $F$. succinogenes varied between approximately 0.5 and $6 \%$ of the population depending on the animal and diet consumed.

When cellulolytic bacteria are grown together in diculture, cellulose degradation is often below that of the pure culture alone (Dehority \& Scott, 1967; Dehority, 1973), which is probably the result of competitive and non-competitive interactions between cellulolytic bacteria. Shi et al. (1997) demonstrated that cell numbers of individual species were approximately equal in celluloseexcess dicultures of $R$. albus plus $R$. flavefaciens, $R$. albus plus $F$. succinogenes, and $R$. flavefaciens plus $F$. succinogenes. However, when cellulose was limiting, $R$. flavefaciens $>R$. albus, R. flavefaciens $>F$. succinogenes, and F. succinogenes $>R$. albus. These competitive outcomes were likely the result of the superior ability of $R$. flavefaciens to adhere to cellulose (Shi \& Weimer, 1996). It is interesting to note that $R$. albus survived under cellulose-limited conditions. This was probably a combination of its ability to utilize glucose (R. flavefaciens does not; Helaszek \& White, 1991), to grow at low concentrations of cellobiose (Shi \& Weimer, 1997) and to produce bacteriocins (Odenyo et al., 1994a).

A fuller understanding of how bacteria survive as members of consortia or cooperative networks is critical if we wish to advance the field of ecosystem biomodification. In relation to fibre degradation, the issue of bacteriocin production by certain cellulolytic bacteria has only recently being explored and is likely to be an essential component in the formation of cooperative microbial networks. $R$. albus strains can produce bacteriocin-like substances that inhibit the growth of $R$. flavefaciens but not of $F$. succinogenes (Odenyo et al., $1994 a, b)$. There also appears to be an unusually high incidence of bacteriocin-like activity among Butyrivibrio isolates and butyrivibriocin has been isolated from $B$. fibrisolvens AR10 (Kalmokoff \& Teather, 1997). How the ability to produce bacteriocins or resistance to bacteriocins are involved in the establishment and persistence of dosed ruminal bacteria is not known, but these compounds are likely to have important ecological consequences.

There were no significant improvements in DMI, DMD or DDMI (Tables 3 and 4). These results demonstrate that increasing the numbers of cellulolytic bacteria in the rumen to the extent that fibre digestion is improved is very difficult. In the dosing protocol used, we hoped that the microbial population would be perturbed to a sufficient extent to allow the introduced bacteria to establish and multiply. This proved not to be the case as shown by the molecular ecology measurements (Fig. 3). These data are confirmed by those of Dehority \& Tirabasso (1998) who could not demonstrate any improvement in the proportion of cellulose digested with a 10 -fold increase in the number of cellulolytic bacteria in the rumen.

It is clear from these studies that an improvement in fibre digestion in vivo is not a foregone conclusion simply because the dosed strains have been maintained at elevated levels in the rumen. The strains used for inoculation were selected using in vitro criteria and it is not known if these strains could be classified as 'superior' in vivo. For this to be done in situ, techniques for strain evaluation would have to be developed and a functional genomic approach could be taken in which the levels of expression of key enzymes are monitored. It is also known that fibrolytic strains can undergo subtle changes in phenotype because of repeated transfer under laboratory conditions. It is likely that key 'elements' are lost from the strains and many of these could be critical for the ability of strains to colonize and persist in vivo. Future studies should identify and evaluate these 'elements'.

\section{ACKNOWLEDGEMENTS}

We would like to thank Brian Dalrymple, Kari Gobius and Gang Ping Xue for useful discussions in relation to this work. We would also like to thank Meat and Livestock Australia for partially funding this work. 


\section{REFERENCES}

Alm, E. W., Oerther, D. B., Larsen, N., Stahl, D. A. \& Raskin, L. (1996). The oligonucleotide probe database. Appl Environ Microbiol 62, 3557-3559.

Amann, R. I., Krumholz, L. \& Stahl, D. A. (1990). Fluorescentoligonucleotide probing of whole cells for determinative, phylogenetic, and environmental studies in microbiology. J Bacteriol $172,762-770$.

Attwood, G. T., Lockington, R. A., Xue, G. P. \& Brooker, G. P. (1988). Use of a unique gene sequence as a probe to enumerate a strain of Bacteroides ruminicola introduced into the rumen. Appl Environ Microbiol 54, 534-539.

Beever, D. E., Coelho da Silva, J. F., Prescott, J. H. D. \& Armstrong, D. G. (1972). The effect in sheep of physical form and stage of growth on the sites of digestion of a dried grass. 1. Sites of digestion of organic matter, energy and carbohydrate. $\mathrm{Br} J \mathrm{Nutr}$ 28, 347-356.

Bryant, M. P. (1972). Commentary on the Hungate technique for culture of anaerobic bacteria. Am J Clin Nutr 25, 1324-1328.

Caldwell, D. E., Wolfaardt, G. M., Korber, D. R. \& Lawrence, J. R. (1997). Do bacterial communities transcend Darwinism? In Advances in Microbial Ecology, pp. 105-191. Edited by J. W. Jones. New York: Plenum.

Coleman, G. S. \& Sandford, D. C. (1979). The engulfment and digestion of mixed rumen bacterial species by single and mixed species of rumen ciliate protozoa grown in vivo. J Agric Sci 92, 729-742.

Dehority, B. A. (1973). Hemicellulose degradation by rumen bacteria. Fed Proc 32, 1819-1824.

Dehority, B. A. \& Scott, H. W. (1967). Extent of cellulose and hemicellulose digestion in various forages by pure cultures of cellulolytic rumen bacteria. J Dairy Sci 50, 1136-1141.

Dehority, B. A. \& Tirabasso, P. A. (1998). Effect of ruminal cellulolytic bacterial concentrations on in situ digestion of forage cellulose. J Anim Sci 76, 2905-2911.

Flint, H. J., Bisset, J. \& Webb, J. (1989). Use of antibiotic resistance mutations to track strains of obligately anaerobic bacteria introduced into the rumen of sheep. J Appl Bacteriol 67, 177-183.

Forsberg, C. W., Cheng, K. J. \& White, B. A. (1997). Polysaccharide degradation in the rumen and large intestine. In Gastrointestinal Microbiology, vol. 1, pp. 319-379. Edited by R. I. Mackie \& B. A. White. New York: Chapman \& Hall.

Fox, G. F., Wisotzkey, J. D. \& Jurtshuk, J. P. (1992). How close is close: $16 \mathrm{~S}$ rRNA sequence identity may not be sufficient to guarantee species identity. Int J Syst Bacteriol 42, 166-170.

Helaszek, C. T. \& White, B. A. (1991). Cellobiose uptake and metabolism by Ruminococcus flavefaciens. Appl Environ Microbiol 57, 64-68.

Hespell, R. B., Akin, D. E. \& Dehority, B. A. (1997). Bacteria, fungi, and protozoa of the rumen. In Gastrointestinal Microbiology, vol. 2, pp. 59-141. Edited by R. I. Mackie, B. A. White \& R. E. Isaacson. New York: Chapman \& Hall.

Hicks, R. E., Amann, R. I. \& Stahl, D. A. (1992). Dual staining of natural bacterioplankton with 4',6-diamidino-2-phenylindole and fluorescent oligonucleotide probes targeting kingdom-level 16SrRNA sequences. Appl Environ Microbiol 58, 2158-2163.

Hungate, R. E. (1950). The anaerobic mesophilic cellulolytic bacteria. Bacteriol Rev 14, 1-49.

Hungate, R. E. (1984). Microbes of nutritional importance in the alimentary tract. Proc Nutr Soc 43, 1-11.

Kalmokoff, M. L. \& Teather, R. M. (1997). Isolation and charac- terization of a bacteriocin (Butyrivibriocin AR10) from the ruminal anaerobe Butyrivibrio fibrisolvens AR10: evidence in support of the widespread occurrence of bacteriocin-like activity among ruminal isolates of B. fibrisolvens. Appl Environ Microbiol 63, 394-402.

Krause, D. O. \& Russell, J. B. (1996). An rRNA approach for assessing the role of obligate amino acid-fermenting bacteria in ruminal amino acid deamination. Appl Environ Microbiol 62, 815-821.

Krause, D. O., Bunch, R. J., Smith, J. M. \& McSweeney, C. S. (1999a). Diversity of Ruminococcus strains: a survey of genetic polymorphisms and plant digesting ability. J Appl Bacteriol 86, 487-495.

Krause, D. O., Dalrymple, B. P., Smith, W. J., Mackie, R. I. \& McSweeney, C. S. (1999b). $16 \mathrm{~S}$ rDNA sequencing of Ruminococcus albus and Ruminococcus flavefaciens: design of a signature probe and its application in adult sheep. Microbiology 145, 1797-1807.

Krause, D. O., Smith, W. J. M., Ryan, F. M. E., Mackie, R. I. \& McSweeney, C. S. (1999c). Use of 16S-rRNA based techniques to investigate the ecological succession of microbial populations in the immature lamb rumen: tracking of a specific strain of inoculated Ruminococcus and interactions with other microbial populations in vivo. Microb Ecol 38, 365-376.

Lin, C., Flesher, B., Capman, W. C., Amann, R. I. \& Stahl, D. A. (1994). Taxon specific hybridization probes for fibre-digesting bacteria suggest novel gut-associated Fibrobacter. Syst Appl Microbiol 17, 418-424.

Lin, C., Raskin, L. \& Stahl, D. A. (1996). Microbial community structure in gastrointestinal tracts of domestic animals: comparative analysis using rRNA-targeted oligonucleotide probes. FEMS Microbiol Ecol 22, 281-294.

Littell, R. C., Henry, P. R. \& Ammerman, C. B. (1998). Statistical analysis of repeated measures data using SAS procedures. J Anim Sci 76, 1216-1231.

Mackie, R. I. \& Wilkens, C. A. (1988). Enumeration of anaerobic bacterial microflora of the equine gastrointestinal tract. Appl Environ Microbiol 54, 2155-2160.

McSweeney, C. S. (1989). Cannulation of the rumen in cattle and buffaloes. Aust Vet J 66, 266-268.

McSweeney, C. S., Palmer, B., Bunch, R. \& Krause, D. O. (2001). Effect of the tropical forage calliandra on microbial protein synthesis and ecology in the rumen. J Appl Microbiol 90, 78-88.

Miller, T. L. \& Wolin, M. J. (1979). Fermentations by saccharolytic intestinal bacteria. Am J Clin Nutr 32, 164-172.

Miyagi, T., Kaneichi, K., Aminov, R. I., Kobayashi, Y., Sakka, K., Hoshino, S. \& Ohmiya, K. (1995). Enumeration of transconjugated Ruminococcus albus and its survival in the goat rumen ecosystem. Appl Environ Microbiol 61, 2030-2032.

Newbold, C. J. \& Hillman, K. (1990). The effect of ciliate protozoa on the turnover of bacterial and fungal protein in the rumen of sheep. Lett Appl Microbiol 11, 100-102.

Nielsen, P. E. (1999). Applications of peptide nucleic acids. Curr Opin Biotechnol 10, 71-75.

Odenyo, A. A., Mackie, R. I., Stahl, D. A. \& White, B. A. (1994a). The use of $16 \mathrm{~S}$ rRNA-targeted oligonucleotide probes to study competition between ruminal fibrolytic bacteria: development of probes for Ruminococcus species and evidence for bacteriocin production. Appl Environ Microbiol 60, 3688-3696.

Odenyo, A. A., Mackie, R. I., Stahl, D. A. \& White, B. A. (1994b). The use of 16S rRNA-targeted oligonucleotide probes to study competition between ruminal fibrolytic bacteria: pure-culture 
studies with cellulose and alkaline peroxide-treated wheat straw. Appl Environ Microbiol 60, 3697-3703.

Raabe, R. (1968). An efficient method of excreta collection from caged sheep. Lab Pract 17, 217-218.

Rijpens, N. P., Jannes, G., Van Asbroeck, M., Rossau, R. \& Herman, L. M. F. (1996). Direct detection of Brucella spp. in raw milk by PCR and reverse hybridization with 16S-23S rRNA spacer probes. Appl Environ Microbiol 62, 1683-1688.

Russell, J. B. (1985). Fermentation of cellodextrins by cellulolytic and non-cellulolytic rumen bacteria. Appl Environ Microbiol 49, 572-576.

Sawada, H., Takeuchi, T. \& Matsuda, I. (1997). Comparative analysis of Pseudomomonas syringae pv. actinidiae and $\mathrm{pv}$. phaseolicola based on phaseolotoxin-resistant ornithine carbamolytransferase gene $(\operatorname{argK})$ and 16S-23S rRNA intergenic spacer sequences. Appl Environ Microbiol 63, 282-288.

Sharp, R., Hazlewood, G. P., Gilbert, H. J. \& O’Donnell, A. G. (1994). Unmodified and recombinant strains of Lactobacillus plantarum are rapidly lost from the rumen by protozoal predation. J Appl Bacteriol 76, 110-117.

Shi, Y. \& Weimer, P. J. (1996). Utilization of individual cellodextrins by three predominant ruminal cellulolytic bacteria. Appl Environ Microbiol 62, 1084-1088.

Shi, Y. \& Weimer, P. J. (1997). Competition for cellobiose among three predominant ruminal cellulolytic bacteria under substrateexcess and substrate-limited conditions. Appl Environ Microbiol 63, 743-748.

Shi, Y., Odt, C. L. \& Weimer, P. J. (1997). Competition for cellulose among three predominant ruminal cellulolytic bacteria. Appl Environ Microbiol 63, 734-742.

Stahl, D. A., Flesher, B., Mansfield, H. R. \& Montgomery, L. (1988). Use of phylogenetically based hybridization probes for studies of ruminal microbial ecology. Appl Environ Microbiol 54, 1079-1084.

Ulyatt, M. J. \& MacRae, J. C. (1974). Quantitative digestion of fresh herbage by sheep. 1 . The sites of digestion of organic matter, energy, readily fermentable carbohydrate, structural carbohydrate, and lipid. J Agric Sci 82, 295-307.

Van Gylswyk, N. O. (1970). The effect of supplementing a lowprotein hay on the cellulolytic bacteria in the rumen of sheep and on the digestibility of cellulose and hemicellulose. J Agric Sci 74, 169-180.

Varel, V. H., Yen, J. T. \& Kreikemeier, K. K. (1995). Addition of cellulolytic clostridia to the bovine rumen and pig intestinal tract. Appl Environ Microbiol 61, 1116-1119.

Vinuesa, P., Rademaker, J. L. W., De Bruijn, F. J. \& Werner, D. (1998). Genotypic characterization of Bradyrhizobium strains nodulating endemic woody legumes of the Canary Islands by PCR-restriction fragment length polymorphism analysis of genes encoding 16S rRNA (16S rDNA) and 16S-23S rDNA intergenic spacers, repetitive extragenic palindromic PCR genomic fingerprinting, and partial 16S rDNA sequencing. Appl Environ Microbiol 64, 2096-2104.

Von Wintzingerode, F., Landt, O., Ehrlich, A. \& Göbel, U. B. (2000). Peptide nucleic acid-mediated PCR clamping as a useful supplement in the determination of microbial diversity. Appl Environ Microbiol 66, 549-557.

Weimer, P. J. (1996). Why don't ruminal bacteria digest cellulose faster? J Dairy Sci 79, 1496-1502.

Wolin, M. J. \& Miller, T. L. (1988). Microbe-microbe interactions. In The Rumen Microbial Ecosystem, pp. 343-359. Edited by P. N. Hobson. New York: Elsevier.

Zheng, D., Alm, E. W., Stahl, D. A. \& Raskin, L. (1996). Characterization of universal small-subunit rRNA hybridization probes for quantitative molecular microbial ecology studies. Appl Environ Microbiol 62, 4504-4513.

Received 11 January 2001; revised 8 March 2001; accepted 15 March 2001. 